\section{BUDGET}

PERSPECTIVES

2020

PAPER 2

June 2019

\section{ASSESSING THE DISTRIBUTIONAL IMPACT OF BUDGETARY POLICY}

\section{THE ROLE OF BENCHMARKS AND INDEXATION}

TIM CALLAN, CLAIRE KEANE AND MARK REGAN

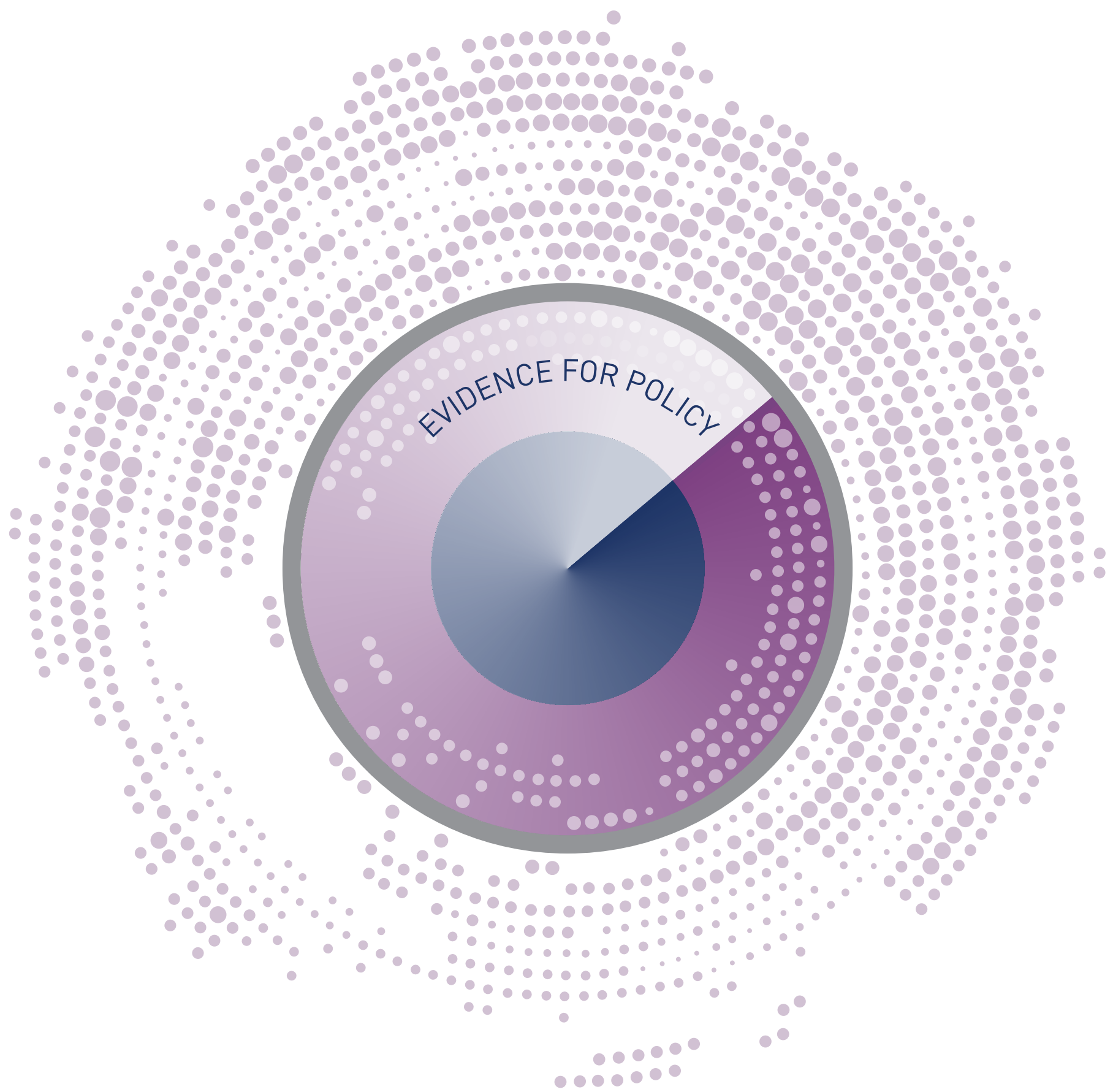




\section{ASSESSING THE DISTRIBUTIONAL IMPACT OF BUDGETARY POLICY: THE ROLE OF BENCHMARKS AND INDEXATION}

Tim Callan

Claire Keane

Mark Regan

June 2019

BUDGET PERSPECTIVES 2020

PAPER 2

Available to download from www.esri.ie

DOI: https://doi.org/10.26504/bp202002

(C) 2019 The Economic and Social Research Institute

Whitaker Square, Sir John Rogerson's Quay, Dublin 2 


\section{ABOUT THE ESRI}

The mission of the Economic and Social Research Institute is to advance evidence-based policymaking that supports economic sustainability and social progress in Ireland. ESRI researchers apply the highest standards of academic excellence to challenges facing policymakers, focusing on 12 areas of critical importance to 21st-century Ireland.

The Institute was founded in 1960 by a group of senior civil servants led by Dr T.K. Whitaker, who identified the need for independent and in-depth research analysis to provide a robust evidence base for policymaking in Ireland.

Since then, the Institute has remained committed to independent research and its work is free of any expressed ideology or political position. The Institute publishes all research reaching the appropriate academic standard, irrespective of its findings or who funds the research.

The quality of its research output is guaranteed by a rigorous peer review process. ESRI researchers are experts in their fields and are committed to producing work that meets the highest academic standards and practices.

The work of the Institute is disseminated widely in books, journal articles and reports. ESRI publications are available to download, free of charge, from its website. Additionally, ESRI staff communicate research findings at regular conferences and seminars.

The ESRI is a company limited by guarantee, answerable to its members and governed by a Council, comprising 14 members who represent a cross-section of ESRI members from academia, civil services, state agencies, businesses and civil society. The Institute receives an annual grant-in-aid from the Department of Public Expenditure and Reform to support the scientific and public interest elements of the Institute's activities; the grant accounted for an average of 30 per cent of the Institute's income over the lifetime of the last Research Strategy. The remaining funding comes from research programmes supported by government departments and agencies, public bodies and competitive research programmes.

Further information is available at www.esri.ie 


\section{THE AUTHORS}

Tim Callan is a consultant economist, Claire Keane is a Senior Research Officer at the Economic and Social Research Institute (ESRI), and Mark Regan is a Research Assistant at the ESRI.

\section{ACKNOWLEDGEMENTS}

This work was undertaken as part of the Tax, Welfare and Pensions programme at the ESRI funded by the Departments of Employment Affairs and Social Protection; Health; Children and Youth Affairs; and Finance. We thank the CSO for access to the SILC data on which the SWITCH tax-benefit model is based. We would like to acknowledge comments received at an internal ESRI seminar as well as the comments from two anonymous referees and from Barra Roantree of the ESRI.

This paper has been accepted for publication by the Institute, which does not itself take institutional policy positions. The paper has been peer reviewed prior to publication. The authors are solely responsible for the content and the views expressed. 


\section{TABLE OF CONTENTS}

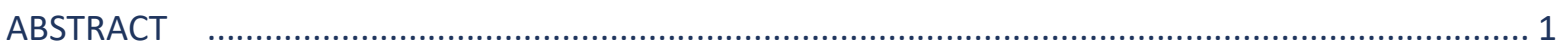

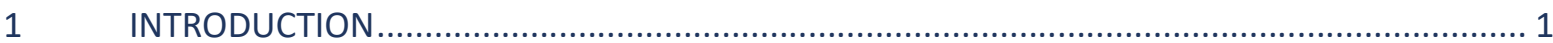

2 THE ROLE OF DEFAULT POLICIES FOR TAX AND WELFARE UPRATING ................................. 3



2.2 Variation across time

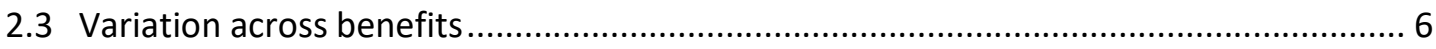

2.4 Implications of alternative indexation policies ................................................................ 6

3 WHAT IS THE BEST BENCHMARK AGAINST WHICH TO MEASURE THE DISTRIBUTIONAL IMPACT OF POLICY?

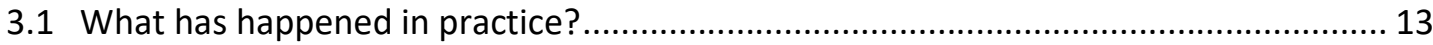

4 INDEXATION OF THE SYSTEM AS A WHOLE - INDIRECT TAXES AND NON-CASH BENEFITS ..... 15

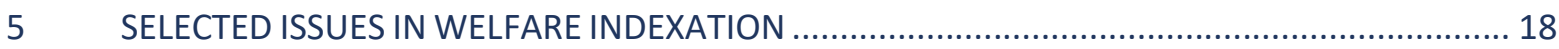

6 THE COST AND DISTRIBUTIONAL IMPACT OF INDEXATION CHOICES: BUDGET 2020.............. 21



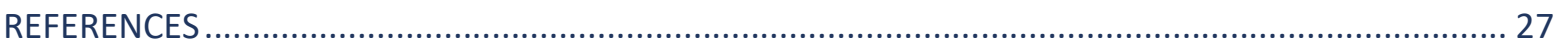




\section{LIST OF TABLES}

Table 1 Indexation regimes for mandatory earnings-related pensions..........................................5

Table 2 Uprating policy for uk basic state pension, 1948-2019 ................................................ 6

Table 3 Impact of alternative benchmark policies on key indicators ........................................12

Table 4 Impact of policy changes on income inequality indicator, selected EU countries, 2001-

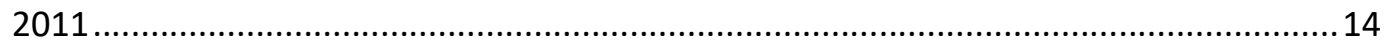

Table 5 Impact of policy changes on AROP indicator, selected EU countries, 2001-2011..........15

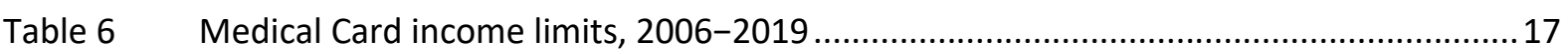

Table 7 Payment rates for Jobseeker's Benefit and State Contributory Pension, selected years,

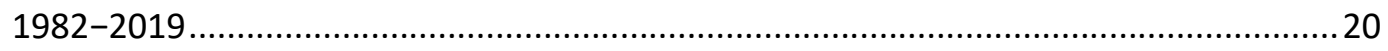

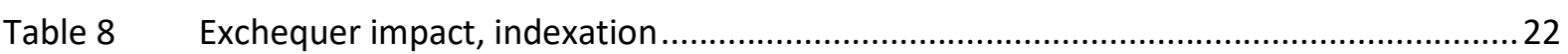

\section{LIST OF FIGURES}

Figure 1 Distributional changes arising from non-indexation (nominal freeze) ............................. 8

Figure 2 Distributional changes arising from price indexation of tax and welfare parameters....... 9

Figure 3 Distributional changes arising from market income indexation of tax and welfare

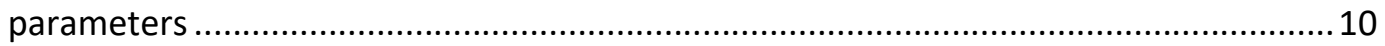

Figure $4 \quad$ Medical Card holders as a proportion of the population............................................18

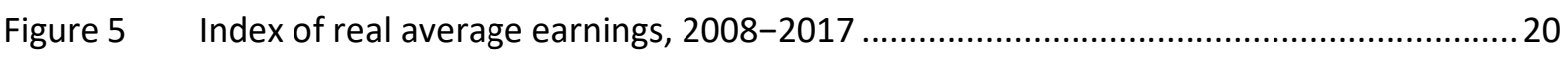

Figure 6 Distributional impact of non-indexation in line with price inflation (direct/indirect taxes and benefits): \% change in disposable income

Figure 7 Distributional impact of non-indexation in line with wage inflation (direct taxes and benefits) and price inflation (indirect taxes): \% change in disposable income 


\title{
ASSESSING THE DISTRIBUTIONAL IMPACT OF BUDGETARY POLICY: THE ROLE OF BENCHMARKS AND INDEXATION
}

\begin{abstract}
This paper examines the potential role for increasing social welfare rates, along with tax credits and bands, in line with price or wage inflation - a process known as indexation. Ireland currently has a default policy of no increases in line with inflation, with ad hoc changes instead announced on Budget day. The recent 'Pensions Roadmap' commits to 'a process whereby future changes in pension rates of payment are explicitly linked to changes in the consumer price index and average wages', and the Minister for Employment Affairs and Social Protection has also announced the intention to examine an index-linked system for the wider welfare system. In light of these discussions, the paper examines how Ireland compares to other countries with regard to indexation. It also examines the impact that different indexation options have on income inequality and poverty over time. Both nominal freezes in taxes and social welfare rates and increases in line with price inflation result in an increase in poverty and income inequality in the longer run. Indexation in line with wage inflation, however, helps keep poverty rates and income inequality more constant in the longer run. Indexation would, of course, represent a cost to the Exchequer - for Budget 2020 we estimate that indexation of the tax-benefit system would cost in the region of $€ 462$ million, while indexation in line with average wage increases would cost in excess of $€ 1.2$ billion.
\end{abstract}

\section{INTRODUCTION}

Governments make two kinds of choices about budgetary policy. They decide what is the default policy ${ }^{1}$ if no budgetary adjustment is made, and they decide on Budget day adjustments relative to that default. A great deal of attention is paid to the announced policy changes, but much less attention is given to the default policies. $^{2}$

In this paper we clarify the role played by these default policies, which vary across countries and over time. We examine the implications of alternative default policies for real incomes at different income levels, for inequality and poverty, and for the Exchequer. We then turn to a distinct issue, informed by the analyses of alternative forms of indexation: the choice of a benchmark against which to assess the distributional impact of budgetary policy. Are governments' default policies such as Ireland's nominal freeze, or the UK's mixture of price indexation for most

\footnotetext{
We use the term 'default policy' to refer to whatever indexation rule - or lack of rules - apply in the absence of an explicit budgetary policy change.

In the Irish fiscal landscape, the default policies construct what is termed the 'opening budget'.
} 
tax and welfare benefits, ${ }^{3}$ with a 'triple lock' on the basic pension - suitable as a benchmark? Or is a benchmark that is independent of governments' choice of default policy better suited to this role? We examine the issues involved and argue that an independent benchmark that is neutral in distributional terms is preferable. We also explore the longer-run evolution of policies measured against such an independent benchmark, drawing on results from Ireland and a number of other EU countries. ${ }^{4}$

The Pensions Roadmap (Government of Ireland, 2018) commits to the development of proposals that will 'institute a process whereby future changes in pension rates of payment are explicitly linked to changes in the consumer price index and average wages', with a 'formal benchmark target of $34 \%$ of average earnings for State Pension contributory payments'. The Minister for Employment Affairs and Social Protection has also recently discussed plans to examine aligning social welfare rate increases with a particular index (Bray, 2019). The issues we examine are highly relevant in this context.

Related issues arise with respect to the adjustment of indirect taxes, which are defined in terms of monetary amounts per specific quantity (e.g. duties on alcohol, tobacco and petrol). We consider these issues and suggest that indexation of these taxes in line with broader price inflation provides an appropriate benchmark. We examine the costs of indexation in line with prices, or with wages, in the context of Budget 2020. How much of the nominal 'fiscal space' would be required simply to index tax and welfare parameters, to ensure a distributionally neutral budget? Our estimates take account of the costs of indexing for income taxes and welfare, but also the Exchequer gains from indexing relevant indirect taxes. Finally, we examine the distributional impact of failing to index the tax-benefit system.

The paper is structured as follows. In Section 2 we examine the default policy adjustments that have commonly been adopted by governments, and their implications for the distribution of income and for the Exchequer. Section 3 examines the choice of a benchmark or standard against which to measure the distributional impact of a government's year-to-year policy changes. It also examines some recent evidence on the overall impact of policy changes on the distribution of income for a range of European countries over the medium term and compares this with some results for Ireland over a longer period. The issue of ensuring indexation of the tax-benefit system as a whole is examined in Section 4. In section 5 we examine some selected issues regarding indexation. The costs and distributional impact of alternative indexation strategies are estimated in Section 6, in the context of Budget 2020. The key findings are drawn together in Section 7.

Price indexation means that benefits are frozen in real terms - as is the case for working-age benefits in the UK until 2020.

4 Our focus throughout is on households, in terms of taxes, welfare payments and net incomes; issues relating to corporate taxes and the impact on firms are not within the remit of this paper. 


\section{THE ROLE OF DEFAULT POLICIES FOR TAX AND WELFARE UPRATING}

There is wide variation in the default policies for year-to-year adjustment of tax and benefit policies along several dimensions. The starting point for many countries - including Ireland - has been that policy changes are announced on a discretionary basis, year by year: no systematic uprating rule is applied. However, the experience of high wage-price inflation during the 1970s and early 1980s led to changes in this procedure in a number of countries. One of the driving forces for this was the phenomenon known as 'fiscal drag' or 'bracket creep', i.e. high growth in nominal wages without concomitant increases in tax bands, leading to a higher proportion of income being taxed at higher rates. ${ }^{5}$ Buchanan's writings on public choice theory (see Reisman, 1989 for a useful overview) identify this as facilitating a 'stealth tax', with the average tax rate rising. Heinemann's (2001) empirical analysis confirms that higher inflation is associated with higher average tax rates.

A key point is that there is a parallel issue in relation to social security and social welfare payments. If benefit payment rates do not keep pace with price inflation, welfare recipients experience losses of real income. When, as has usually been the case, nominal wage growth is faster than price inflation, there are similar issues in terms of relative income: if benefit rates do not keep pace with growth in real incomes, then the incomes of those dependent on welfare fall in relation to average living standards. Paulus et al. (2019) term this 'benefit erosion'.

In what follows, we illustrate the substantial differences in uprating or indexation policies across countries, over time, and as between tax and benefit instruments.

\subsection{Variation across countries}

Sutherland et al. (2008) provide an overview of the tax and welfare uprating procedures (or lack of procedures) across a wide range of countries. ${ }^{6}$ Drawing on this work, we can illustrate the great variety of the approaches then in force, including the following.

\section{Denmark:}

- Uprating is unified and comprehensive.

- All benefit and tax parameters are systematically indexed with respect to average earnings - with a small lag, and a small deduction.

In fact, in the calculation of fiscal space the government counts the non-indexation of the tax system as a revenueraising measure: see IFAC (2018).

6 We focus here on the scale of adjustment to money-valued welfare and tax parameters. Sutherland et al. (2008) document a range of other differences in the adjustment procedures, including the legal basis (automatic or at the initiative of government), coverage (full system or selected elements) and the role of the political process (statutory provision with the possibility of suspension, versus no legal provision but regular de facto adjustment). 
Finland:

- The basic means-tested pension, family benefits and minimum income scheme are indexed in line with price inflation.

- By contrast, earnings-related pensions are linked to a weighted average of price inflation ( $80 \%$ weight) and wage growth ( $20 \%$ weight).

- Income tax parameters are adjusted on a discretionary basis, with frequent de facto adjustment.

Sweden:

- Most benefits are adjusted in line with prices.

- Earnings-related pensions are linked to average earnings growth less $1.6 \%$, so typically are growing in real terms but falling in relation to average incomes.

Australia:

- Most benefits are indexed in line with price inflation.

- Income tax thresholds are changed through discretionary procedures.

- The means-tested old age pension also has provision for a link to the consumer price index (CPI), but the lower limit of $25 \%$ of average weekly earnings has been the driving force instead.

New Zealand:

- Most benefits are linked to CPI.

- Pension (NZ Superannuation) follows CPI, but subject to a floor of 65 per cent and a ceiling of 72.5 per cent of average earnings.

Sutherland et al (2008) summarise the situation with respect to these and other countries in their study:

Besides a very few examples of automatic and unified earnings uprating, the most common practice remains adjustment linked to prices ... When uprating is to some extent linked to earnings, this is limited to pension payments, while the rest of the tax-benefit system parameters are linked to price movements.

De Agostini et al. (2014) note that in many EU countries, indexation rules were changed - typically in a less generous direction - as austerity policies were introduced following the Great Recession. This provides further evidence on temporal as well as cross-national variations. 


Indexation regime
No automatic indexation, discretionary changes only
Price indexation

Weighted average or other combination of price indexation and indexation with respect to wage or income changes

Wage indexation

Countries
Austria
Belgium, Canada, France, Hungary, Iceland, Italy,
Korea, Poland, Turkey, USA
Czech Republic, Estonia, Finland, Greece, Japan,
Latvia, Luxembourg, Portugal, Slovak Republic,
Switzerland
Germany, Netherlands, * Norway, Slovenia,
Sweden

Source: OECD (2017), Table 3.6

Note: $\quad *$ The change is conditional on financial sustainability in this country. Japan: wage indexation to age 67 , followed by price indexation thereafter. Norway: indexation to wage growth minus $0.75 \%$. Sweden: wage growth minus $1.6 \%$.

While pensions are often treated differently from other benefits, there is also very substantial variation across countries in the uprating procedures for pension benefits. We illustrate this using information on the uprating procedures for mandatory, earnings-related pension schemes in OECD countries. Even within this specific type of pension scheme, there is considerable cross-country variation. Some countries opt for price indexation, others for wage indexation, while a substantial number provide for uprating that takes the form of a combination (often a weighted average) of price and wage developments.

\subsection{Variation across time}

The experience of high inflation, as noted earlier, led to changes in the uprating procedures for taxes in a number of countries. In the UK, with price inflation running at 16 per cent, a backbench amendment by Rooker and Wise succeeded in introducing indexation of personal income tax allowances and tax bands. This has been in place since 1977. The US legislated in 1981 for indexation in line with price inflation with effect from 1985. These procedures are still in force. In Germany, the government has an obligation to report to parliament on the extent of 'bracket creep' (measured with respect to price inflation) every two years, but there is no obligation to adjust brackets (Dorn et al., 2017). These appear to be 'one-off' changes in uprating practice, but not all variations over time are of this type.

The extent to which indexation or uprating policy can vary over time is well illustrated by the case of the UK's Basic State Pension (BSP). As shown in Table 2, over the years between 1974 and 2011, policy moved from having no systematic uprating rule to one that adopted the higher of wage growth or price inflation, followed by more than 20 years based purely on price inflation. Currently the system provides for a 'triple lock', with pensions being uprated by the highest of earnings growth, price inflation or 2.5 per cent. 


\begin{tabular}{|l|l|}
\hline $\begin{array}{l}\text { Period } \\
\text { 1948-1974 }\end{array}$ & \multicolumn{1}{c}{ Yearly decisions, no uprating rule } \\
\hline $\mathbf{1 9 7 5 - 1 9 8 0}$ & Higher of wage growth and price inflation \\
\hline $\mathbf{1 9 8 0 - 2 0 0 2}$ & Price inflation \\
\hline $\mathbf{2 0 0 3 - 2 0 1 0}$ & Higher of 2.5\% and price inflation \\
\hline $\mathbf{2 0 1 1 -}$ & 'Triple lock': highest of earnings growth, price inflation or 2.5\% \\
\hline
\end{tabular}

Source: Bozio et al. (2010).

\subsection{Variation across benefits}

We have noted already that many countries have different uprating procedures for pension benefits as against all other benefits. There can, however, be further differences even within the pensions sphere, with different practices operating on means-tested as against insurance-based benefits for example. Disney (2016) notes that four different uprating systems are in use in the UK for different elements of the pension system:

When the 'triple lock' was introduced in 2010, it applied to the then Basic State Pension (BSP). The Additional State Pension (ASP) was to continue to be indexed to the Consumer Price Index (CPI). Hence the BSP component would likely grow faster than the ASP. Confusingly, too, the Minimum Guarantee to the Pension Credit would continue to be uprated in line with earnings, whilst the Saving Credit component of the Pension Credit could be uprated 'as the Secretary of State sees fit.

\subsection{Implications of alternative indexation policies}

In order to understand the implications of different default options, we focus on three of the most commonly adopted defaults: non-indexation (leaving moneyvalued parameters at the same nominal level), indexation in line with price inflation, and indexation in line with a measure of growth in earnings or incomes. ${ }^{7}$ Indexation is applied (or not) to money-valued parameters such as tax credits, tax bands and welfare payment rates. We explore the implications of implementing each of these options on incomes at different levels across the full income distribution, using SWITCH, ${ }^{8}$ the ESRI tax-benefit model, to ensure that a nationally representative picture is obtained. We also examine the impact on the Exchequer balance - the extent to which it moves towards surplus or towards deficit.

In order to explore the impact of implementing various default policies, we construct a basic economic scenario which includes key features of long-run

The focus in this section is on direct taxes and the Local Property Tax; Section 4 considers issues relating to indirect taxes.

8 See Box 1 for more information on SWITCH. 
experience. Later, we consider some potential complications arising from shortrun variations from this long-run path. Over the long run, economic growth means that nominal incomes have risen at a faster rate than prices, so that real incomes have grown. Economic growth can involve dislocations and trends which result in changes in the household income distribution. We can get a clearer view of the impact of default policies' impacts by constructing a scenario in which all market incomes ${ }^{9}$ rise at the same rate - we abstract from the challenges posed by rising market income inequality or factors reducing market income inequality.

This scenario is one in which prices rise at 2 per cent per year, and incomes grow more rapidly than prices, so that there is also real income growth of 2 per cent. We consider outcomes after a period of five years, meaning that prices rise by close to 10.5 per cent, and nominal incomes by almost 22 per cent.

Currently, the Local Property Tax liabilities depend on valuations as of 2013. Latest indications (O'Halloran (2019), quoting An Taoiseach) are that a revaluation initially scheduled for 2019 will not now take place until 2020 at earliest, and that bands and rates will be reformed to ensure that any property tax changes would be 'modest'. In our analysis, we construct such a property tax change by applying a reduced rate of tax to higher property tax values, so that the aggregate property tax revenue represents the same proportion of household income in the end period (after five years of growth in incomes and higher growth in property values) as in the base period. ${ }^{10}$ This is a 'middle path' between recent practice - property tax bills being fixed by 2013 valuations - and the application of unchanged property tax rates to a higher property tax value. ${ }^{11}$ At a technical level, this approach also allows the construction of policy scenarios in which both income and property taxes rise in line with incomes, so that the aggregate tax to income ratio remains constant - a feature of a fiscally neutral scenario.

The precise details of the numbers used for income growth and prices are not essential to our findings. The key feature is that real incomes grow over the long run. The patterns observed in terms of distributional changes, and the direction of the impact on the Exchequer balance, are the key outcomes. The scale of the impact will depend on the precise numbers, and on the number of years included in the analysis. We present results classified by deciles of household disposable income per adult equivalent, using the equivalence scale used by the CSO in the measurement of 'at risk of poverty' (AROP), i.e. 1 for the first adult in the household, 0.66 for other adults, and 0.33 for each child. Each decile contains $10 \%$ of households, ranked from the lowest incomes (bottom) to the highest incomes (top).

Market income here is defined as including incomes from employment, self-employment, interest, dividends and rent, and occupational pensions in payment (but excluding State Contributory and Non-Contributory pensions).

10 Note that while growth in property tax revenue would be linked to income growth, the structure of liabilities would still reflect property values rather than income.

11 For more details on options for restructuring of the Local Property Tax see Thornhill (2015); for analysis of the impact of a revaluation on revenue see O'Connor and Lynch (2016) 
Figure 1 shows the outcomes in this scenario if tax and welfare parameters are frozen in nominal terms. There are losses in real income for those with the lowest incomes, as the real value of unchanged welfare payments is eroded by inflation. At higher incomes, there are gains in real disposable incomes, of between 3 and 5 per cent - well below the cumulative growth in real earnings of just over 10 per cent. There is therefore an increase in overall income inequality. The AROP rate (the proportion of the population with incomes below 60 per cent of median household income per adult equivalent) rises by almost 3 percentage points. The net Exchequer balance improves, by close to $€ 9.8$ billion per annum, as the tax to GNP ratio rises and the expenditure to GNP ratio falls.

\section{FIGURE 1 DISTRIBUTIONAL CHANGES ARISING FROM NON-INDEXATION (NOMINAL FREEZE)}



The net effect is reported. Analysis over a period of five years with assumed real income growth of 2 per cent.

Figure 2 illustrates the outcomes under the alternative of price indexation of tax and welfare parameters. There are gains in real income across the income distribution, with smaller gains for those on low incomes and larger gains for those in the upper half of the distribution. This pattern reflects the fact that welfare payments as a proportion of total income decline when moving from low income to high income deciles. With welfare payments frozen in real terms, and real gains in market incomes (employment and self-employment), this gives rise to the pattern shown. Even with the highest of these gains (just over 7 per cent for the top decile), gains are well below the rise of 10.4 per cent in real pre-tax incomes. Again, there is an increase in inequality, and the risk of poverty rises by 1.6 percentage points. The tax to GNP ratio rises, and the expenditure to GNP ratio falls, with a saving to the Exchequer in the region of $€ 5.7$ billion per annum. 




Note: The net effect is reported. Analysis over a period of five years with assumed real income growth of 2 per cent.

In Figure 3, by contrast, households' real incomes increase at almost the same rate across the full income distribution. Incomes rise by just over 10 per cent on average, and for each income decile. ${ }^{12}$ As Paulus et al. (2019) state, this is 'a fiscally neutral scenario', with 'a neutral treatment of households on benefit and those with earnings - if household market incomes were rising (falling) in real terms, households on benefit would gain (lose) in real terms'. There is no change in income inequality and the risk of poverty remains constant. The Exchequer gains by $€ 1.6$ billion per annum, reflecting simply the increase in scale of the economy.

12 There are minor variations (from 10.2 to 10.4 per cent). These arise because of a variety of elements in the tax-benefit system that lead to liabilities or benefits not rising in line with income; for example, mortgage interest relief at source depends on the size of mortgages, which is influenced by house prices, and rent supplement/Housing Assistance Payment (HAP) may be influenced by developments in the rental market. 


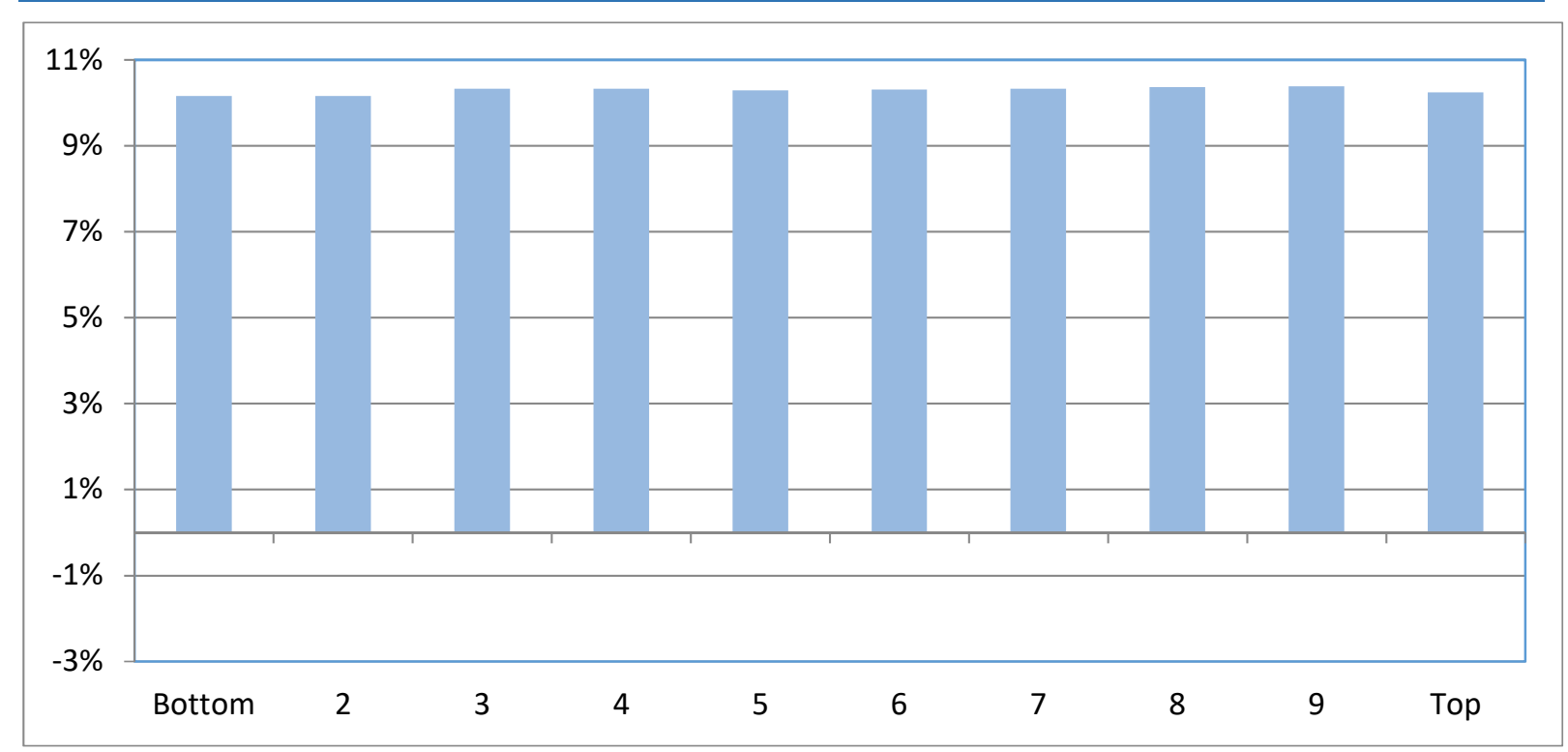

Note: The net effect is reported. Analysis over a period of five years with assumed real income growth of 2 per cent.

Real-world indexation schemes are often more complex than the simple, single uprating approaches examined here. But the trends identified in our analysis carry through in more complex cases. Sutherland et al. (2008) examine the impact of uprating benefits, tax credits and direct tax thresholds in line with the UK's current policies for a period of 20 years. These involve widespread indexation in line with prices, with the basic state pension receiving a more favourable treatment (the highest of wage growth, price inflation or 2.5 per cent). They find a benefit to the public finances of up to 3.6 per cent of GDP. At the same time, the incomes of 'a considerable part of the poorer non-pensioner population would fall behind those of the population as a whole ... and relative poverty would rise'. Child poverty would almost double, from 18 per cent to 33 per cent. 


\section{Box 1: SWITCH, the ESRI's tax-benefit model}

The SWITCH (Simulating Welfare and Income Tax Changes) model is based on a representative sample of the Irish population consisting of pooled data from the CSO's Survey of Income and Living Conditions (SILC). SILC is an annual household survey conducted by the Central Statistics Office (CSO) in order to obtain information regarding the income and living conditions of Irish households. The SWITCH database consists of nearly 10,000 households.

The sample of households used to construct the SWITCH database contains all households from the 2015 survey, and all additional households from the 2014/2013 surveys that were not interviewed in 2015. This ensures that households in SILC are present only once in the SWITCH database. Basing the model on SILC means that it represents as fully as possible the great diversity of household circumstances relevant to tax and social welfare.

The data are adjusted to be representative of the 2019 population in terms of income levels, unemployment rates, etc. Data weights ensure that income tax yields, social welfare expenditure and so on can be grossed up to population levels. The model can simulate the disposable income each family would obtain under a variety of income tax and social welfare policies, real or proposed. SWITCH can then be used to estimate the Exchequer impact of alternative policies as well as the distributional impact on households' incomes (i.e. the percentage change in income by decile or family type due to the policy changes).

The SWITCH model provides a detailed and accurate representation of almost all aspects of the personal tax and benefit system. Expenditure information is not available in the underlying SILC survey; nor does it does account for expenditure on public services, which, unlike cash transfers provided through the benefit system, are conceptually difficult to value and assign at a household level ( $O^{\prime}$ Dea and Preston, 2014).

\section{WHAT IS THE BEST BENCHMARK AGAINST WHICH TO MEASURE THE DISTRIBUTIONAL IMPACT OF POLICY?}

We can use the information presented in the previous section to illuminate another question: What benchmark should we use when evaluating the distributional impact of changes in tax and welfare policy ${ }^{13}$ First, we consider whether the default policy chosen by government can play such a role. Then we examine each of the three standards examined earlier (nominal freeze, price indexation and wage or income indexation) as potential benchmarks for analysis of distributional impacts of budgetary policy.

13 The total policy change here includes both the default policy and changes announced on Budget day. 
Should we use the government's default policy as a benchmark for examining distributional impact? This is the standard used in many Budget day documents in Ireland, where the default policy is, for the most part, to keep nominal tax and welfare parameters constant at the pre-existing level. But there are serious problems with this approach. Default policies can change over time - so the measured impact of government policy depends on what government chooses as its default policy. Governments could, therefore, manipulate the measured impact on this approach by their choice of default policy.

An example may help to illustrate this. Suppose a government proposed an extreme measure such as abolishing the welfare system, or the income tax system, over its period of government. It could therefore declare its default policy to include abolition in equal steps over five years. If the default policy were used as the yardstick for assessment of policy changes, then the measured impact would be zero in each year. This reductio ad absurdum clearly demonstrates the conceptual flaws in the use of government-chosen default options as a yardstick for assessment of policy changes. Changes over time, and across benefits, mean that to build an evaluation approach based on governments' default options is to build on shifting sands. Paulus et al. (2019) make a similar point, stressing that the choice of a benchmark policy 'is not related to what governments aim to do, or actually do - the role of the benchmark index is to offer a yardstick against which to measure the progress of actual government policies, and each benchmark has a specific economic interpretation' (emphasis in original).

\begin{tabular}{|c|c|c|}
\hline & $\begin{array}{l}\text { Indexed in line with prices, or frozen in } \\
\text { nominal terms }\end{array}$ & $\begin{array}{l}\text { Indexed in line with } \\
\text { wages/incomes }\end{array}$ \\
\hline $\begin{array}{l}\text { Government spending as } \\
\text { share of national income }\end{array}$ & Decrease & Constant \\
\hline $\begin{array}{l}\text { Income tax as \% of national } \\
\text { income }\end{array}$ & Increase & Constant \\
\hline $\begin{array}{l}\text { Exchequer balance moves } \\
\text { towards surplus }(+) \text { or deficit } \\
(-)\end{array}$ & Lower deficit/higher surplus & Constant \\
\hline Distributional impact & $\begin{array}{l}\text { Increased inequality, greater rise in real } \\
\text { income for high incomes than for low } \\
\text { incomes }\end{array}$ & $\begin{array}{l}\text { Neutral, same rise in real } \\
\text { income across all income } \\
\text { deciles }\end{array}$ \\
\hline $\begin{array}{l}\text { Increase/decrease in AROP } \\
\text { rate }\end{array}$ & Increase & Constant \\
\hline
\end{tabular}

Next we turn to the evaluation of the three approaches examined in Section 2: tax and welfare values that are unchanged in nominal terms, increased in line with price inflation, or increased in line with growth in a measure of wages or incomes. 
Table 3 summarises key features of each of these candidates for use as a benchmark.

Given that one of our aims is to assess distributional outcomes, a key feature is that the nominal freeze and price indexation approaches are not neutral in distributional terms. Under the scenario used here, with nominal wages growing faster than prices, the frozen tax and welfare parameters, or indexing them in line with price inflation, involve an increase in inequality. Only the wage/income indexation approach provides a distributionally neutral outcome against which to measure the impact of policy choices. Similarly, in macroeconomic terms, only the wage/income indexed benchmark leads to neutrality in the sense of unchanged ratios of tax and expenditure to national income.

Comparisons with a price-indexed policy can be of interest for other reasons - for example, to monitor the impact of policy developments on the real value of welfare benefits. But it must be recognised that a benchmark of 'no change in real terms' involves non-neutral outcomes for welfare recipients and taxpayers. Thus, for a more comprehensive analysis of the distributional impact of policy, it is essential to include analysis relative to a distributionally neutral benchmark, such as is provided by a wage- or income-indexed policy.

Overall, this evidence provides a strong case for using wage/income indexation as the benchmark for evaluation of the distributional outcomes of the budget. A similar case was made by Callan et al. (2001) and underpins the regular assessments of distributional impacts of budgetary policy by the ESRI (most recently, Roantree et al. (2018)).

It should be noted that our approach does not imply what government policy 'ought to be'; it merely advocates measuring actual policy against a distributionally neutral policy. One can also measure against a benchmark of 'constant real values', but it must be realised that this involves distributional changes. Actual distributional targets are a matter for societal and governmental decision: our analysis is designed to provide clearer information on the consequences of alternative decisions.

\subsection{What has happened in practice?}

Default policies can influence eventual outcomes. The potential for 'fiscal drag' may make it easier for governments to make choices that increase tax rates and reduce benefits relative to other incomes. But default policies do not determine the outcomes - discretionary changes can override the defaults to arrive at any preferred outcome. Sutherland et al. (2008) note that countries with statutory indexation can sometimes suspend this default policy, while 'regular adjustments might be applied in countries where there is no statutory provision for automatic indexation as part of the budget process (in Ireland, Germany and New Zealand, for example)'.

Paulus et al. (2019) examine the total impact of policy changes in a selection of 
countries, with differing uprating regimes. The full period examined is 2001 to 2011, which includes the strong growth of 2001 to 2007, and the recession/lowgrowth period of 2007 to 2011 . Their analysis includes the full period and the two sub-periods, and we summarise the key features of relevance to the present paper below. $^{14}$

Table 4 examines the impact of policy changes (including both default options and discretionary changes over and above the defaults) on income inequality as measured by the Gini coefficient for disposable income. While some of the countries examined have automatic indexation with respect to prices, none has systematic uprating with respect to nominal wage growth. Thus, where real wage growth is positive, regular adoption of automatic uprating as final policy would lead to increased inequality, as examined in Section 2. However, Paulus et al. find that over the full period, five of the seven countries examined saw policy changes that reduced inequality, as measured by the Gini coefficient. In three cases (Belgium, Greece and Italy) real wages were roughly constant - in these cases price indexation would have sufficed to ensure stability of income inequality. But the outcomes in these cases show reductions in income inequality. Of the other four cases, two (Estonia and the UK) show reductions in inequality and two (Bulgaria and Hungary) show increases in income inequality.

\begin{tabular}{|l|l|l|l|l|}
\hline Country & \multicolumn{3}{|c|}{$\begin{array}{c}\text { Change in Gini coefficient } \\
\text { (\% points) }\end{array}$} & $\begin{array}{c}\text { Real growth in market } \\
\text { Income, 2001-2011 (\%) }\end{array}$ \\
\hline & 2001-2007 & 2007-2011 & 2001-2011 \\
\hline Belgium & $0.2^{*}$ & $-0.8^{*}$ & $-0.6^{*}$ & 0 \\
\hline Bulgaria & $0.6^{*}$ & $0.9^{*}$ & $1.4^{*}$ & 61 \\
\hline Estonia & $-0.4^{*}$ & $-0.6^{*}$ & $-1.1^{*}$ & 57 \\
\hline Greece & 0 & $-0.6^{*}$ & $-0.6^{*}$ & 1 \\
\hline Hungary & 0.1 & $2.2^{*}$ & $2.3^{*}$ & 14 \\
\hline Italy & $-1.3^{*}$ & $0.2^{*}$ & $-1.1^{*}$ & -3 \\
\hline UK & $-0.6^{*}$ & $-0.7^{*}$ & $-1.3^{*}$ & 11 \\
\hline
\end{tabular}

Source: Paulus et al. (2019).

Note: $\quad P$ values: $*<0.01, \dagger<0.05, \ddagger<0.10$.

Table 5 shows results from a parallel analysis of policy impacts on the AROP rate. Over the full period, policy impacts in 6 of the 7 countries are found to be in the direction of reducing the risk of poverty. For Ireland, a longer run analysis is available from last year's ESRI Budget Perspectives (Callan et al., 2018). This shows that, despite the absence of any formal indexation mechanism, regular uprating of

14 We do not attempt a full interpretation of the results shown, which reflect a great many inter-country differences in terms of the composition of the population (e.g. share of the elderly, unemployment rate) and the make-up of the welfare system. 
tax and welfare policies in the Budget, coupled with policy reforms, tended to reduce the risk of poverty by 1 percentage point. These results confirm the importance of the total impact of policy, rather than focusing simply on indexation mechanisms. For example, indexation in line with prices could lead to welfare payments falling relative to average earnings; but non-indexation, as in the Irish case, accompanied by regular discretionary changes can lead to welfare payments keeping pace with earnings.

IMPACT OF POLICY CHANGES ON AROP INDICATOR, SELECTED EU COUNTRIES, 2001-2011

\begin{tabular}{|l|l|l|l|l|}
\hline Country & \multicolumn{3}{c|}{ Change in AROP (\% points) } & $\begin{array}{c}\text { Real growth in market } \\
\text { income (2001-2011) }\end{array}$ \\
\hline & & & & \\
\hline & $2001-2007$ & $2007-2011$ & $2001-2011$ & \\
\hline Belgium & $0.5 \ddagger$ & $-2.1^{*}$ & $-1.6^{*}$ & 0 \\
\hline Bulgaria & $-0.9+$ & 0.1 & -0.8 & 61 \\
\hline Estonia & $-2.0^{*}$ & $-1.6^{*}$ & $-3.6^{*}$ & 57 \\
\hline Greece & -0.2 & $-0.4 \ddagger$ & $-0.6 \ddagger$ & 1 \\
\hline Hungary & $2.3^{*}$ & $0.6 \dagger$ & $2.9^{*}$ & 14 \\
\hline Italy & $-1.2^{*}$ & 0 & $-1.2^{*}$ & -3 \\
\hline UK & $-3.0^{*}$ & $-0.4^{*}$ & $-3.4^{*}$ & 11 \\
\hline
\end{tabular}

Source: $\quad$ Paulus et al. (2019).

Note: $\quad P$ values: $*<0.01, \uparrow<0.05, \ddagger<0.10$.

\section{INDEXATION OF THE SYSTEM AS A WHOLE - INDIRECT TAXES AND NON-CASH BENEFITS}

So far, this paper has considered the rationale and impact of indexation of the direct tax and cash benefit system. It is important, however, to consider indexation of the tax-benefit system as a whole.

Indirect taxes either are calculated as a percentage of the price of a good or are charged by quantity at a nominal rate. The main indirect taxes in Ireland are Value Added Tax (VAT), which is levied on most goods and services on a percentage basis, and excise duties such as the tobacco products tax, alcohol products tax and the solid fuel carbon tax (SFCT), which are levied at a fixed rate per commodity unit. As discussed in Thirsk (1997), both direct and indirect taxes need to be indexed, particularly during periods of high inflation, in order to maintain real tax revenues and avoid distortions in the tax treatment of commodities and help avoid inflationinduced inequities.

Indirect taxes calculated as a percentage of the commodity price, such as VAT, will naturally rise as the price of the commodity rises. In the absence of indexation, indirect taxes calculated as a nominal amount per commodity unit will result in a real fall in such taxes as prices rise, a situation known as 'fiscal boost' - the opposite 
to the 'fiscal drag' phenomenon discussed in Section 2. Therefore, while indexation of tax parameters and social welfare rates will cost the Exchequer, indexation of these indirect taxes will generate revenue. In order to keep these nominal indirect taxes at a constant rate relative to the commodity price, indexation of such taxes in line with prices would be a natural approach. The current default in the Irish system is no automatic adjustment in these nominal, indirect tax rates - rather ad hoc adjustments are announced on Budget day.

The idea of indexation of the system as a whole is an important one. In the absence of indexation of the income limits for means tested non-cash benefits, fewer individuals will be eligible for such benefits as earnings and cash benefits rise. One such non-cash benefit is the General Medical Services (GMS) scheme, which awards Medical and GP-Visit Cards to families satisfying a means test. ${ }^{15}$ Indeed, a recent Parliamentary Question ${ }^{16}$ to the Minister for Health highlighted the issue of increasing State Pensions and the adverse effects this may have, with such increases sending some cardholders above the means limit. His response was:

Budget 2019 provided for increases in a number of social welfare payments which are intended to come into effect in March 2019. It would be the Government's intention that people's ability to qualify for a medical card would not be adversely affected by this increase. I have asked the HSE [Health Service Executive] to monitor the situation and to advise me if it considers that changes in the rates of social welfare payments may affect people's ability to qualify for a medical card.

(Simon Harris TD, Minister for Health, 22 January 2019)

IN FACT THE INCOME LIMITS FOR THE MEDICAL CARD HAVE REMAINED UNCHANGED SINCE 2006 (SEE

Table 6) while the income limits for the GP-Visit Card remained unchanged ${ }^{17}$ between 2006 and 2019, when they were increased by 10\%. Over this period wage growth was relatively modest $(+4.3$ per cent growth in average hourly regular earnings between 2008 and $2018^{18}$ ), in large part due to a decline in earnings during the recession.

15 Some Medical and GP-Visit Cards are awarded on a discretionary basis to individuals who have means above the relevant limit but are deemed to be at risk of undue hardship in the absence of the card. GP-Visit cards are also awarded to all individuals aged over 70 or under six.

16 Available online at https://www.oireachtas.ie/en/debates/question/2019-01-22/319/

17 Until 2019 income limits for GP-Visit cards were 50 per cent higher than those for Medical Cards.

18 Taken from the CSO's Earnings Hours and Employment Costs Survey (EHECS). No data available for 2006/2007. 


\begin{tabular}{|c|c|c|}
\hline Category & $\begin{array}{l}\text { Aged under } 66 \\
\text { years }(€)\end{array}$ & $\begin{array}{c}\text { Aged over } 66 \\
\text { years }(€)\end{array}$ \\
\hline Single person living alone & 184 & 201.50 \\
\hline Single person living with family & 164 & 173.50 \\
\hline $\begin{array}{l}\text { Couple, married/cohabiting/civil partners (or lone parent with } \\
\text { dependent children) }\end{array}$ & 266.50 & 298 \\
\hline Allowance for each of first two children aged under 16 & 38 & 38 \\
\hline Allowance for third and each subsequent child under 16 & 41 & 41 \\
\hline $\begin{array}{l}\text { Allowance for each of first two children aged over } 16 \text { (with no } \\
\text { income) }\end{array}$ & 39 & 39 \\
\hline $\begin{array}{l}\text { Allowance for third and each subsequent child over } 16 \text { (with no } \\
\text { income) }\end{array}$ & 42.50 & 42.50 \\
\hline $\begin{array}{l}\text { Each dependant over } 16 \text { in full-time third-level education, who is } \\
\text { not grant-aided }\end{array}$ & 78 & 78 \\
\hline
\end{tabular}

Note: Weekly income limit (gross less tax, Universal Social Charge and PRSI) after childcare, housing and travel to work costs.

Figure 4 shows the proportion of the population who hold a Medical Card. Despite the freezing of income limits from 2006 onwards, this proportion rose as the effects of the recession were felt, with a rise in unemployment and a fall in earnings ${ }^{19}$ occurring. Coverage rates fell from $40 \%$ in 2012 to $34 \%$ in 2017 as the economy and earnings recovered and unemployment rates fell.

19 For example, average, regular earnings in the EHECS fell from €34,186 in 2009 to $€ 33,174$ in 2011. 


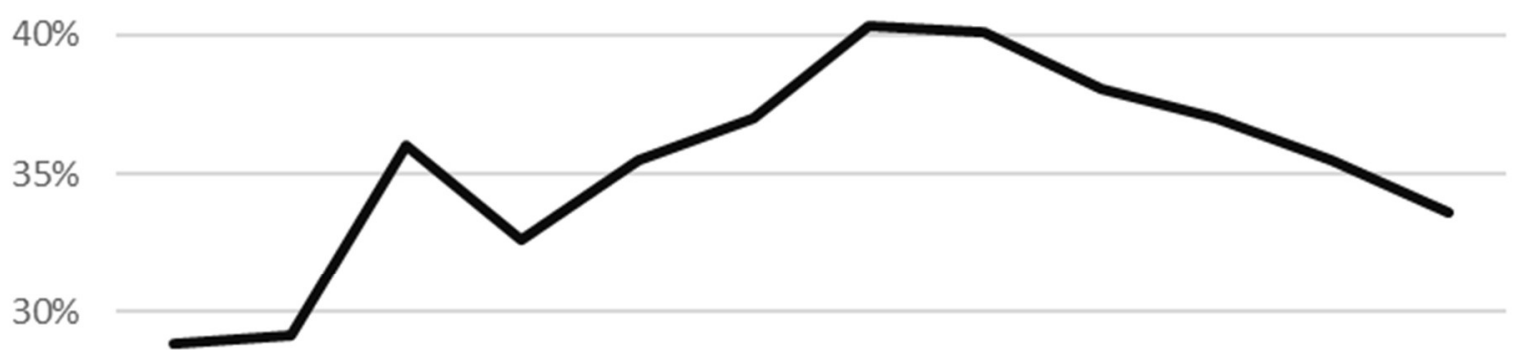

A common indexation policy for cash and means-tested non-cash benefits would remove the need to monitor income levels mentioned above and would ensure that the number of eligible persons does not fall simply due to wage growth and indexation of other components the tax and welfare system.

Similar consideration should be given to income limits for other non-cash benefits such the Affordable Childcare Scheme, which provides mainly means-tested childcare subsidies to parents via childcare providers. Likewise, income limits for Rent Supplement and Differential Rents for Local Authority properties and the HAP would need to be indexed in line with incomes to ensure that increases in earnings and welfare payments do not continually result in higher rent payments for those in receipt of these benefits.

\section{SELECTED ISSUES IN WELFARE INDEXATION}

Discussion of indexation policy for welfare payments in Ireland has centred mainly on the State Contributory pension. One of the earliest statements in this regard was from the Pensions Board (1998):

Having considered the issues raised in relation to both adequacy and coverage, recognising that both the level of pension and the approach to indexation need to be borne in mind, and conscious of the fact that there is no 'right answer' about a rate which could be objectively agreed, the Board considers that the best strategy in order to, firstly, minimise the risk of poverty and, secondly, provide coverage to lower income people in the most efficient way is to set the target pension 
rate at the upper end of the range estimated by the ESRI i.e. f96 per week (in 1996 terms). For reasons of practicality, the Board considers that this target should be expressed as a percentage of average industrial earnings which would equate to around 34 per cent, which seems a 'reasonable' percentage in terms of what a minimum income should be.

This target has been referred to widely in subsequent years, and was restated most recently in the 'Pensions Roadmap' (Government of Ireland, 2018):

In order to protect pension adequacy into the future the Government intends to examine and develop proposals to:

(i) Set a formal benchmark target of $34 \%$ of average earnings for State pension contributory payments and;

(ii) Institute a process whereby future changes in pension rates of payment are explicitly linked to changes in the consumer price index and average wages.

However 'locking-in' pension increases in a formulaic manner may limit discretion to implement other policy priorities in an environment where fiscal space is limited. Accordingly the development of such approaches will require careful design and could only be introduced if accompanied by complementary changes in the funding of the pension system.

There has been some discussion of indexation policy for other welfare payments. Kennedy (2001) looked at the issue of indexation but the Working Group established at the time failed to reach a consensus. NESC (1999) states:

In conclusion, the Council is of the view that, in the longer term, poverty for some categories of the population will increase if social welfare rates do not match increases in average disposable incomes. In view of this, social welfare rates must be linked to improvements in the general standard of living.

This suggests a rather similar mechanism for indexation of all welfare payments. Absent such an approach, the ratio of payments for pensions to that of other welfare rates may vary substantially. This is illustrated by experience over almost four decades in Table 7. 


\begin{tabular}{|l|c|c|c|}
\hline & Jobseeker's Benefit (€/week) & State Contributory Pension (€/week) & 'Pensioner premium' (\%) \\
\hline $\mathbf{1 9 8 2}$ & 40.19 & 51.11 & 27.2 \\
\hline $\mathbf{1 9 8 7}$ & 53.71 & 69.96 & 30.3 \\
\hline $\mathbf{1 9 9 4}$ & 77.45 & 90.15 & 16.4 \\
\hline $\mathbf{2 0 0 0}$ & 98.40 & 121.89 & 23.9 \\
\hline $\mathbf{2 0 0 7}$ & 185.80 & 209.30 & 12.6 \\
\hline $\mathbf{2 0 1 4}$ & 188.00 & 230.30 & 22.5 \\
\hline $\mathbf{2 0 1 9}$ & 203.00 & 248.30 & 22.3 \\
\hline
\end{tabular}

Source: http://www.welfare.ie/en/Pages/SW19-Archive.aspx

Note: $\quad$ Rates of payment for 2000 and earlier years converted from Irish pound to euro. Current nominal values are used throughout, as the focus is on the ratio of the payment rates. The 'pensioner premium' is the percentage by which the SCP rate exceeds the JB rate.

The 'pensioner premium' has oscillated between a high of 30 per cent in 1987 and a low of 13 per cent in 2007, stabilising at around 22 per cent in 2019. It is difficult to rationalise such a pattern in terms of social inclusion goals.

Finally we turn to consideration of cyclical issues. While typically wages rise by more than prices, there are cyclical variations in both of these indices, and at times indexation with respect to real wages would imply falls in real incomes for welfare recipients. Figure 5 shows how real wages fell sharply during the recent recessionary years, then recovered gradually to pre-recession levels.

\section{FIGURE 5 INDEX OF REAL AVERAGE EARNINGS, 2008-2017}

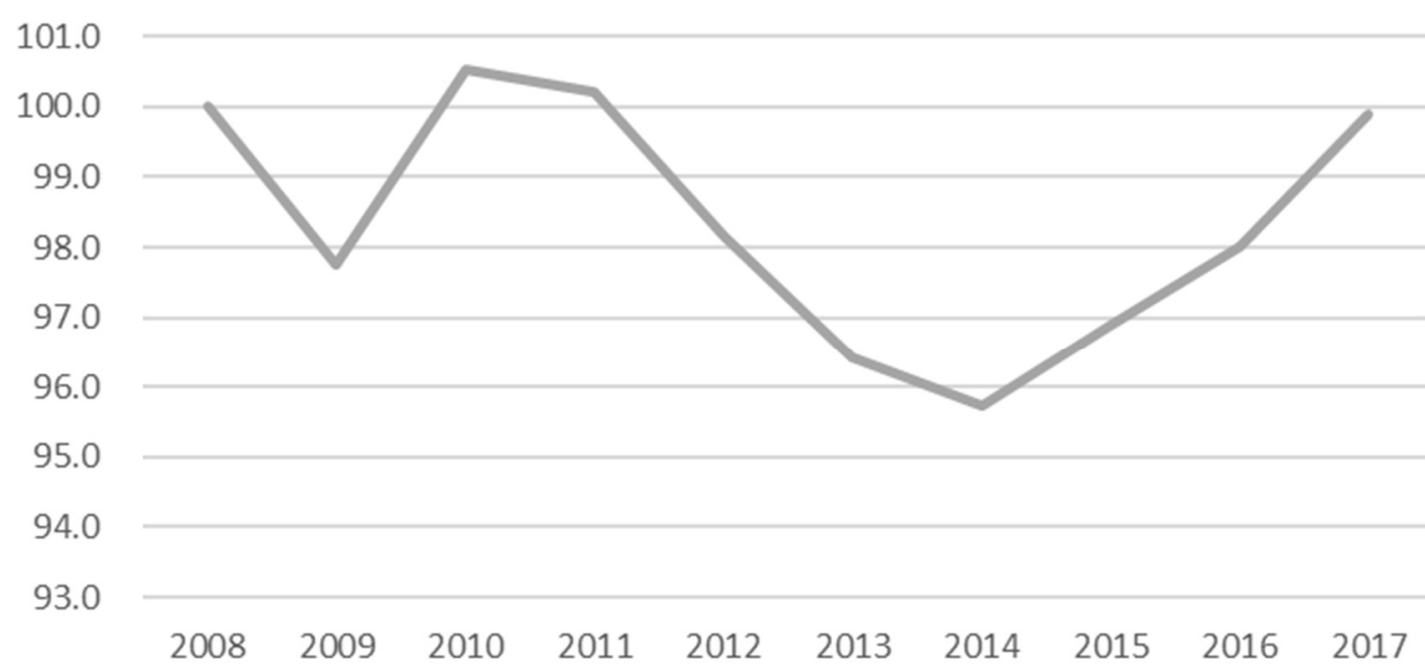

Is it possible to 'smooth' the path of welfare payments when average incomes are falling? This depends partly on the public finance situation. It may also result in indexation leading to 'ratcheting', whereby welfare payments rise at a faster rate 
than both wages and prices in the long run. ${ }^{20}$ Welfare payments must on average follow the real income path of average incomes, so if protected during downturn, they must be less than the full extent of growth in upturns to avoid a ratcheting effect. An alternative that prevents ratcheting is the 'smoothed earnings approach' whereby benefits are indexed in line with wage inflation unless price inflation is higher, in which case benefits are indexed in line with prices. In subsequent years, where wage growth again exceeds price inflation, welfare rates continue to be indexed in line with price inflation until such time as the earnings benchmark is once again restored. Particular care needs to be taken to distinguish between cyclical falls and shifts in long-term trends - potential adjustment paths differ for these.

\section{THE COST AND DISTRIBUTIONAL IMPACT OF INDEXATION CHOICES: BUDGET 2020}

Finally, we examine the cost of indexing direct income taxes, ${ }^{21}$, benefits and indirect nominal taxes, specifically excise duties and carbon taxes. We also examine the distributional impact that would occur if Budget 2020 were to keep taxes and benefit parameters frozen in nominal terms.

SWITCH (see Box 1) is firstly used to calculate households' direct tax liabilities and benefit entitlements under the actual 2019 tax and benefit system. Two counterfactual income distributions are then produced. Under the first, the 2019 tax-benefit system is indexed by anticipated price inflation for 2020, i.e. direct tax thresholds/credits and welfare benefits are increased in line with the forecasted growth in prices. Under the second counterfactual, the 2019 tax-benefit system is indexed by anticipated wage inflation for 2020, i.e. tax thresholds/credits and welfare benefits are increased in line with the forecasted growth in wages. Price inflation is forecast at $+1.4 \%$ for 2020 while wage inflation is forecast to be $+3.5 \%{ }^{22}$

Given that expenditure information is not available in the data underpinning SWITCH, the Household Budget Survey (HBS) is used to estimate the indirect taxes paid by households (including VAT, duties and carbon taxes) under announced 2019 rates. One counterfactual 2020 indirect tax system is produced whereby nominal indirect taxes are increased in line with price inflation estimates - as price inflation is the natural indexation choice for indirect taxes, as discussed earlier.

20 This point was recognised by NESC (1999), who argued that 'Indexation to the higher of inflation or incomes ... creates a "ratchet effect", which means that over a long timeframe SW rates would grow faster than either incomes or inflation. While this could be legitimate during the period of achievement of an agreed benchmark it would not be legitimate or feasible in the long-term.'

21 By 'income taxes' here we mean charges on income such as income tax, USC and PRSI.

22 Price and wage inflation for 2020 are calculated using the average of the ESRI's Quarterly Economic Commentary (QEC) forecast and the Central Bank's Quarterly Bulletin forecast. Both McQuinn et al. (2019) and Central Bank of Ireland (2019) forecast a CPI of $+1.4 \%$ in 2020 . QEC (2019) forecasts a $3.5 \%$ growth in average hourly earnings while Central Bank of Ireland (2019) forecasts $+3.6 \%$ for compensation per employee. 
Table 8 shows the net cost of indexing the tax and welfare ${ }^{23}$ system in 2020 . Indexation of the direct tax and benefit system by price indexation would cost just under $€ 500 \mathrm{~m}$ while price indexation of the indirect tax system would generate nearly $€ 38 \mathrm{~m}$, giving a net Exchequer cost of indexation of $€ 462 \mathrm{~m}$. Meanwhile, wage indexation of the direct tax and benefit system by price indexation would cost nearly $€ 1.3$ billion. The cost of price indexation of the indirect tax system remains at $€ 38 \mathrm{~m}$, giving a net Exchequer cost of indexation of $€ 1.2$ billion. These costs can be put into perspective by comparing them to the fiscal space that was available last year - IFAC (2018) estimated a gross fiscal space of $€ 3.9$ billion for Budget 2019, with non-indexation of the tax system bringing this figure to $€ 4.5$ billion.

\begin{tabular}{|l|l|l|}
\hline & $\begin{array}{c}\text { CPI indexation; } \\
\text { direct/indirect taxes } \\
\text { \& benefits (€m p.a.) }\end{array}$ & $\begin{array}{c}\text { Wage indexation; direct } \\
\text { taxes/benefits. CPI } \\
\text { indexation: indirect } \\
\text { taxes (€m p.a.) }\end{array}$ \\
\hline Indexation Exchequer cost, direct taxes/benefits & 499.8 & $1,265.9$ \\
\hline Indexation Exchequer gain, indirect taxes & 37.8 & 37.8 \\
\hline Net Exchequer cost of indexation & 462.0 & $1,228.0$ \\
\hline
\end{tabular}

Source: Authors' calculations using the 2015-2016 Household Budget Survey and SWITCH run on pooled 2013/2014/2015 Survey of Income and Living Conditions data, both uprated to 2019 incomes and prices.

While indexation of direct tax and benefits would be significantly more costly than price indexation, Figure 3 demonstrates that doing so ensures a neutral treatment of households on benefits and those with earnings and results in a 'fiscally neutral scenario' over the longer run. This compares to a price indexation of direct taxes and benefits that is less costly but leads to larger gains for higher income households and relatively lower gains for lower income households over the longer run, as shown in Figure 2.

A more obvious approach for the indexation of indirect taxes is apparent - indexing these taxes in line with prices would keep these taxes constant in real terms while there is no clear rationale for indexing indirect taxes in line with wages. For these reasons we present the distributional impact of both price and wage indexation of indirect taxes and benefits along with the price indexation of indirect taxes.

To do so we examine the distributional impact that would occur in 2020 if the direct tax-benefit and indirect tax systems were indexed in line with price inflation. We then compare this with the income distribution that would be in place if tax

23 This includes personal rates payments along with increases for qualified adults/children and additional allowances such as the living alone allowance. 
parameters (both direct and indirect) and benefit rates were frozen in nominal terms. Figure 6 shows the differences in these two income distributions.

A lack of indexation of direct tax-benefit system in line with price inflation would result in a regressive pattern with the lowest income decile losing out the most $(-0.9 \%)$ and the highest income decile losing out the least $(-0.3 \%)$. Non-indexation of the indirect tax system in line with prices would result in a progressive pattern with the largest gain for the lowest income decile $(+0.09 \%)$ and the smallest gain $(+0.02 \%)$ for the highest income decile. The negative impact on income of not indexing the direct tax-benefit system in line with prices, however, more than outweighs the gains faced by the lower income deciles due to non-indexation of indirect taxes. Overall, therefore, the net impact remains regressive, with larger losses for lower income households $(-0.8 \%$ of income compared to $-0.3 \%$ for the highest income decile).

FIGURE 6 DISTRIBUTIONAL IMPACT OF NON-INDEXATION IN LINE WITH PRICE INFLATION (DIRECT/INDIRECT TAXES AND BENEFITS): \% CHANGE IN DISPOSABLE INCOME

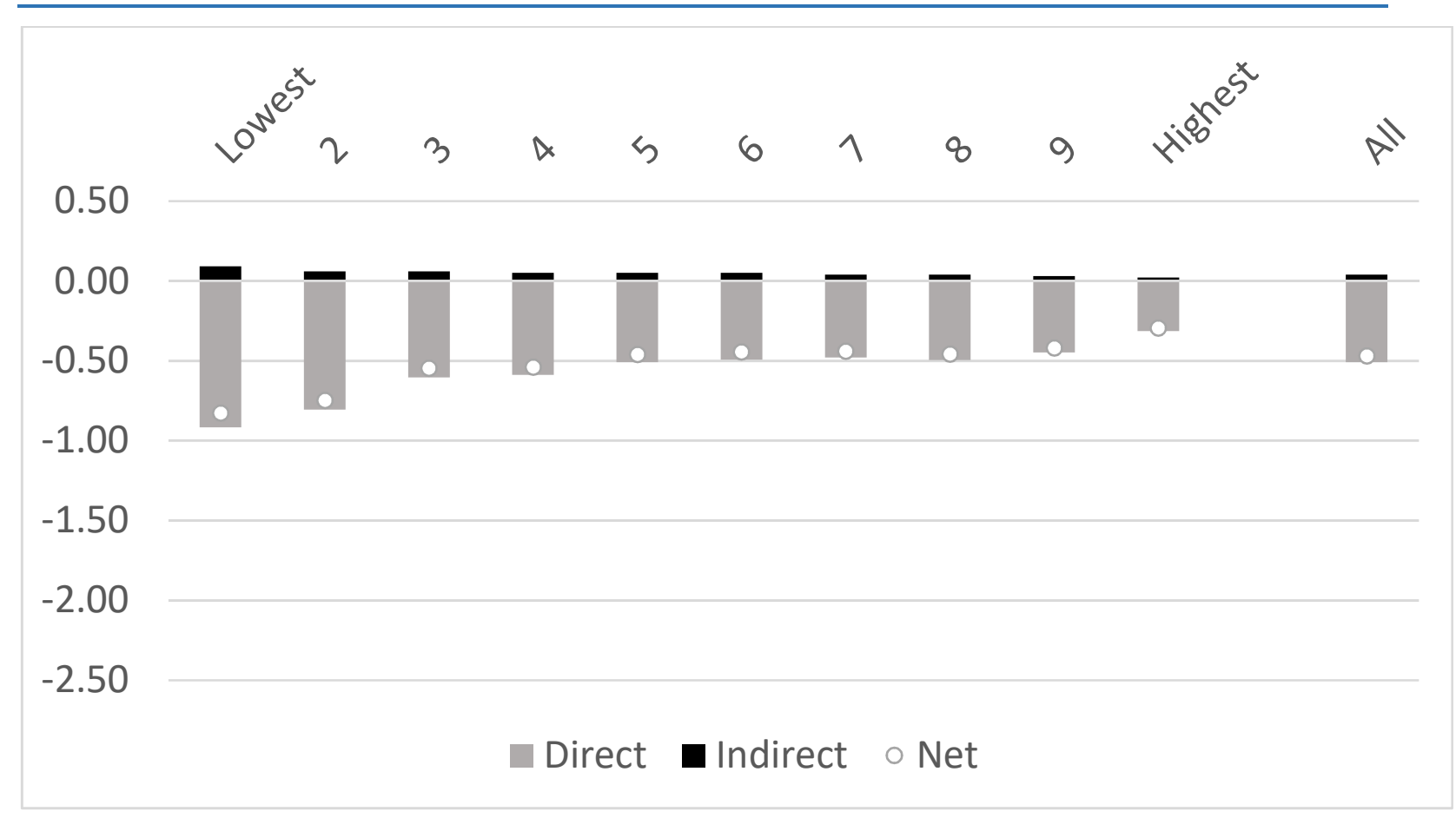

Source: $\quad$ Authors' calculations using the 2015-2016 Household Budget Survey, and SWITCH run on pooled 2013/2014/2015 Survey of Income and Living Conditions data, both uprated to 2019 incomes and prices.

Note: $\quad$ Deciles are based on equivalised household income, using CSO national equivalence scales.

Next we examine the distributional impact that would occur in 2020 if the direct tax-benefit system was not indexed in line with anticipated wage inflation. We continue to assume that the indirect taxation system is not indexed in line with price inflation for reasons discussed above. We compare this income distribution to the one that would be in place if tax parameters (both direct and indirect) and benefit rates were frozen in nominal terms. Figure 7 shows the differences in these two income distributions. 


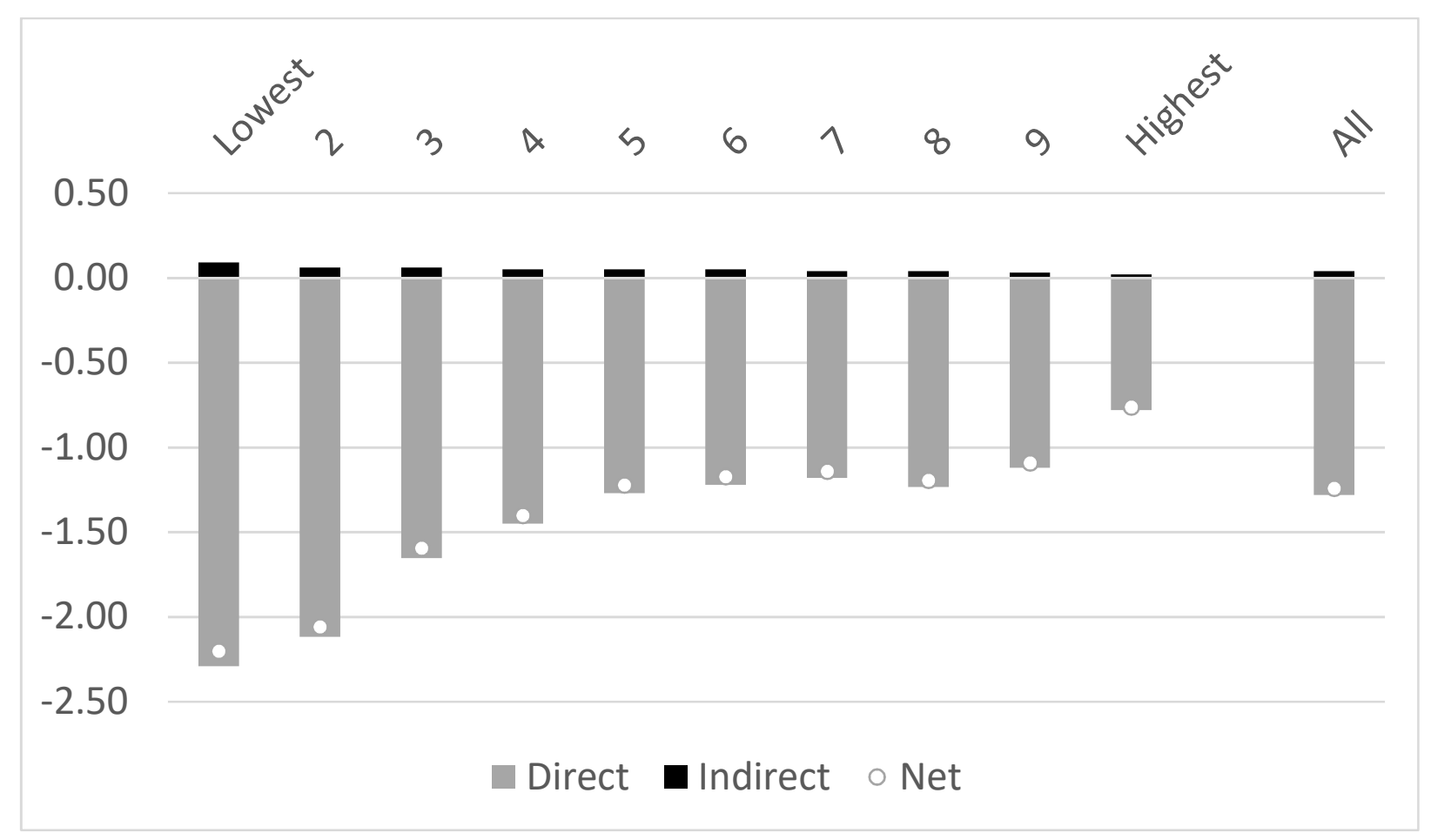

Authors' calculations using the 2015-2016 Household Budget Survey, and SWITCH run on pooled 2013/2014/2015 Survey of Income and Living Conditions data, both uprated to 2019 incomes and prices.

Note: $\quad$ Deciles are based on equivalised household income, using CSO national equivalence scales.

Overall, the same pattern as seen in Figure 6 is observed but the regressive nature of not indexing the direct tax-benefit system by wage inflation is substantially stronger, with the lowest income decile losing out the most $(-2.3 \%)$ and the highest income decile losing out the least $(-0.8 \%)$. The results of not indexing the indirect tax system in line with prices are as before. As before, the net impact remains regressive, with larger losses for lower income households $(-2.2 \%$ of income compared to $-0.8 \%$ for the highest income decile).

\section{CONCLUSIONS}

This paper has examined the issue of indexation, whereby governments may increase tax bands, credits and social transfers in line with price or earnings inflation. It is apparent that there is wide variation in the default chosen by governments across time and across countries and further variation across different elements of the tax-benefit system.

The implications of three commonly used indexation approaches were examined non-indexation (i.e. leaving money valued parameters frozen at the same nominal level), indexation in line with price inflation, and indexation in line with earnings growth. Over the longer run, assuming real growth in incomes ahead of price 
inflation, indexation of tax and welfare parameters in line with earnings growth will result in household real incomes rising at close to the same rate across the income distribution, regardless of whether the income is from earnings or social welfare. This will result in little or no change in income inequality and AROP rates. Indexation in line with price inflation, which tends to be lower than earnings, results in a rise in real income across the income distribution but gains are larger for those at the upper end of the income distribution and smaller for those at the lower end. Non-indexation results in a more regressive pattern, with losses in real income for those at the lower end of the income distribution as inflation erodes the real value of benefit payments, while those on higher incomes receive an increase in real income as earnings growth outstrips price inflation. Both price and non-indexation will result in increased income inequality and poverty rates.

From an Exchequer point of view, tax and expenditure to GNP ratios will remain constant if indexation in line with earnings is adopted. Both indexation in line with prices and non-indexation will result in a rise in the tax and expenditure to GNP ratios as the government gains from a freeze, or increase less than wage inflation, in tax credits, bands and social welfare benefits. Therefore, in evaluating the impact of tax-benefit policy over time, the use of wage-indexed policy parameters has a strong claim on our attention - it results in a fiscally neutral situation over time and provides us with a neutral benchmark against which to assess actual policy changes.

In practice in Ireland, in the absence of a formal indexation process, discretionary changes in tax bands/credits and welfare payments in recent decades have tended to keep pace with earnings growth, resulting in relatively constant poverty rates.

While this paper has mainly focused on the direct tax system (e.g. income taxes, USC, PRSI) and cash welfare benefits, it is also important to consider the tax-benefit system as a whole. Without price indexation, indirect taxes set at a fixed rate per unit of a commodity, such as excise duties and the carbon tax, will fall in real terms over time if not adjusted. Increases in these indirect taxes in line with price inflation is an obvious choice in order to maintain their real value over time. Non-cash benefits are also of importance - unless income levels in means tests for non-cash benefits, such as Medical and GP-Visit cards, childcare and housing subsidies are adjusted in line with earnings inflation, entitlements to such benefits will fall over time as a lower proportion of individuals will satisfy the means test. Consistent approaches across cash benefits would also be required in order to maintain the relative value of different benefits. Consideration must also be given to how benefits should be indexed in times of falling prices or wages and to being conscious of potential ratcheting effects over time, depending on the indexation approach adopted.

Finally, the cost and distributional impacts of price and wage indexation were examined in the content of Budget 2020. Non-indexation of the tax-benefit system would result in losses in income across the income distribution, with sharper 
effects for non-indexation in line with wages when compared to prices. Assuming indexation of indirect taxes in line with prices, price indexation of direct tax and welfare parameters would cost in the region of $€ 462$ million and wage indexation would cost around $€ 1.2$ billion. These costs need to be examined in light of the actual fiscal space available and, ultimately, remain a political decision. 


\section{REFERENCES}

Bozio, A., R. Crawford and G. Tetlow (2010). 'The history of state pensions in the UK: 1948 to 2010 ', Briefing Note, London: Institute for Fiscal Studies.

Bray, J. (2019). 'Regina Doherty signals end to $€ 5$ increases in social welfare payments', Irish Times, 13 January.

Callan, T., M. Keeney, B. Nolan, and J. Walsh (2001). 'Reforming tax and welfare', Policy Research Series Paper No. 42, Dublin: The Economic and Social Research Institute.

Central Bank of Ireland (2019). Quarterly Bulletin, QB1, January, Dublin: CBI.

De Agostini, P., A. Paulus, H. Sutherland, and I. Tasseva (2014). 'The effect of tax-benefit changes on income distribution in EU countries since the beginning of the economic crisis', Research Note 02/2013, Brussels: European Commission.

Disney, R. (2016). 'The triple lock on pensions: an urgent case for change?', London: National Institute of Economic and Social Research.

Dorn, F, C. Fuest, B. Kauder, L. Lorenz, M. Mosler and N. Potrafke (2017). 'How bracket creep creates hidden tax increases: evidence from Germany', ifo DICE Report, 4/2017, December, Vol. 15.

Government of Ireland (2018). A roadmap for pensions reform, 2018-2023. https://www.welfare.ie/en/pressoffice/pdf/PensionsRoadmap.pdf

Heinemann, F. (2001). 'After the death of inflation: will fiscal drag survive?', Fiscal Studies, Vol. 22, No. 4.

IFAC (2018). 'Pre-Budget 2019 statement', https://www.fiscalcouncil.ie/wpcontent/uploads/2018/09/Pre-Budget-2019-Statement.pdf

O'Halloran, M. (2019). 'Changes to property tax delayed until 2020 at the earliest Taoiseach', Irish Times, 16 January.

Kennedy, K. (2001). Final report of the Social Welfare Benchmarking and Indexation Group, Dublin: Department of Social, Community and Family Affairs.

McQuinn, K., C. O'Toole, M. Allen-Coghlan, and P. Economides (2019). Quarterly Economic Commentary, Spring, Dublin: The Economic and Social Research Institute.

NESC (1999). Opportunities, Challenges and Capacities for Choice, Report No. 105, Dublin: National Economic and Social Council.

O'Connor, B. and D. Lynch (2016). 'Analysis of recent property price developments and implications for Local Property Tax liabilities and revenue yield', Administration, Vol. 64, No. 1, pp. 29-60.

O'Dea, C. and I. Preston (2014). 'Can we measure who loses most from public service spending cuts?', Budget Perspectives 2015, Dublin: The Economic and Social Research Institute.

OECD (2017). Pensions at a glance 2017: OECD and G20 indicators, Paris: OECD Publishing. 
Paulus, A., H. Sutherland, and I. Tasseva (2019). 'Indexing out of poverty? Fiscal drag and benefit erosion in cross-national perspective', Review of Income and Wealth, DOI: 10.1111/roiw.12413.

Pensions Board (1998). Securing retirement income: national pensions policy initiative, Report of The Pensions Board to the Minister for Social, Community and Family Affairs, Dublin.

Reisman, D. (1989). The political economy of James Buchanan, Basingstoke: Palgrave Macmillan.

Roantree, B., M. Bercholz, K. Doorley, C. Keane, and M. Regan (2018). 'Budget 2019 - tax and welfare changes', Quarterly Economic Commentary Special Article, Dublin: The Economic and Social Research Institute.

Sutherland, H., R. Hancock, J. Hills, and F. Zantomio (2008). 'Keeping up or falling behind? The impact of benefit and tax uprating on incomes and poverty', Fiscal Studies, Vol. 29, No. 4, pp. 467-498.

Thirsk, W. (ed.) (1997). Tax reform in developing countries (English), World Bank Regional and Sectoral Studies, Washington, DC: The World Bank.

Thornhill, D. (2015). Review of the Local Property Tax (LPT), www.budget.gov.ie/budgets/2016/documents/review_of_local_property_tax_ pub.pdf 
Whitaker Square,

Sir John Rogerson's Quay,

Dublin 2

Telephone +35318632000

Email admin@esri.ie

Web www.esri.ie

Twitter @ESRIDublin 